\title{
Antigen Presentation
}

National Cancer Institute

\section{Source}

National Cancer Institute. Antigen Presentation. NCI Thesaurus. Code C17663.

The event of providing fragments of foreign proteins, including viruses and bacteria, to the helper T cells. The presentation occurs through the display of the fragments of foreign proteins on the surface of the antigen-presenting cells (APC). 